\title{
The Role of Majelis Taklims and Arabic Literacy in Sustaining Lifelong Learning in Indonesia
}

\author{
Didi Suherdi \\ English Education Department \\ Universitas Pendidikan Indonesia \\ Bandung, Indonesia \\ suherdi_d@upi.edu
}

\author{
Dudung Rahmat Hidayat, Maman Abdurrahman \\ Arabic Education Department \\ Universitas Pendidikan Indonesia \\ Bandung, Indonesia
}

\begin{abstract}
This paper concerns the results of a study on the role of Majelis taklims and Arabic literacy in sustaining lifelong education in Indonesia. The study is intended to explore how Majelis taklims and Arabic literacy sustain lifelong learning among Indonesian Muslims in terms of the age groups, topics discussed, time spent, methods, and benefits. To get the data required, questionnaires were distributed to 750 Majelis taklim members in several cities in West Java, and 461 of them were returned and analyzed. The analysis found that although they vary in many respects, yet they share a strong commonality in sustaining their attendance in Majelis taklim. Based on the findings, some suggestions are presented at the end of the paper.
\end{abstract}

Keywords-Majelis taklim; Arabic literacy; lifelong learning; sustenability; ustadzs

\section{INTRODUCTION}

Lifelong learning has been an interesting topic of discussion and serious concern in our world since 1970s. It is considered to be 'the battering ram against inequality [1]; the basis for a 'new renaissance' [2]; and as an everlasting charging agent. In most cases, lifelong learning has been associated with professional development and economic growth, however, as stated by Smethurst [3], in order to succeed in life, we do not only need academic skills but also personality, independence of mind, and autonomy of spirit. This entails the need of learning a wide range of subjects, not only those related to academic, but also to psychological, mental, and spiritual knowledge [4][7]. Hence, lifelong learning is not only concerned with formal or non-formal learning activities, but also informal ones [8]. It is this wider perspective that the writers will take throughout this paper. In Indonesian contexts, this way of viewing lifelong learning is not only relevant, but also motivating and enlightening.

In conjunction with lifelong learning projects in Indonesia, as far as this perspective is concerned, there are three critical issues that needs to be taken into account: the balance between physical and material, and mental and spiritual wellness (See also [9], [10], and [11]); the involvement of formal, non-formal and informal institutions [12], [13]; and the wide range of learning approaches adopted by the 'teachers'. In terms of the first issue, the balance between physical and material, and mental and spiritual wellness, it is argued that mental and spiritual learning is as important as physical and material learning. This means that those who are successful in physical and material life will not reach happy, contented, and sustainable contentment, unless they are also successful in mental and spiritual life. In most cases in Indonesian contexts, those who are successful in mental and spiritual life, although less successful in physical and material life sustain better than those who are successful in physical and material but less successful in mental and spiritual life. This condition may be accounted for the survival of a large number of people who are still living in poverty in the nation. Based on these facts, it is reasonable to argue that mental and spiritual learning is a significant determinant of the true success. Hence, investigating how Indonesians learn mental and spiritual aspects of their life is important.

In relation to the second issue, the involvement of formal, non-formal and informal institutions, it is argued that informal institution plays a key role in Indonesian lifelong learning success. This is, among others, apparent in the role of Majelis taklims and other informal institutions in providing access to the majority of Indonesian adult learners. At last, as for the third issue, the wide range of learning approaches adopted by the 'teachers', it is argued that while some approaches are suitable, others needs improvement as far as successful achievement is concerned.

TABLE I. The NUMBER OF MAJELIS TAKLIM IN JAKARTA PROVINCE

\begin{tabular}{llll}
\hline Tahun & Nama ka... & Lembaga ... & Jumlah \\
\hline 2011 & Kepulauan ... & Majlis Taklim & 60 \\
2011 & Jakarta Selatan & Majlis Taklim & 1617 \\
2011 & Jakarta Timur & Majlis Taklim & 1103 \\
2011 & Jakarta Pusat & Majlis Taklim & 760 \\
2011 & Jakarta Barat & Majlis Taklim & 1365 \\
2011 & Jakarta Utara & Majlis Taklim & 625 \\
\hline
\end{tabular}

Based on the discussion above, understanding the nature of the mental and spiritual sides of lifelong learning, including the characteristics of the participants, the subjects learned, length of time of involvement, the frequency and duration, as well as the benefits, this study takes the role of Majelis taklim and Arabic literacy as its focus. This is important for at least two reasons. First, the number of Majelis taklim is huge. In the Province of Jakarta alone, the number exceeds 5,500 Majelises 
(See Figure 1). It is reasonable to be skeptical about its role in sustaining lifelong learning, especially among Muslims. Second, most, if not all, Muslims are literate in Arabic, especially that which is used to understand Al Quran and its related kitabs (books).

\section{METHODS}

The study used a survey method, in which questionnaires were distributed to respondents in six different areas, including Banjar, Ciamis, Tasikmalaya, Bandung and Cianjur. The questionnaires were designed to cater information on respondents' gender, age groups, attendance, schedule, Al Quran reading Fluency, Arabic writing Fluency, learning materials, frequency, duration, benefits, impacts, language components, and learning methods. Out of 750 questionnaires distributed, 461 were returned. The data was then analyzed and conclusions were drawn. The whole number of the respondents and their groups in terms of gender and age has been summarized and presented in Table II.

TABLE II. THE NUMBER OF RESPONDENTS IN TERMS OF GENDER AND AGE.

\begin{tabular}{llllll}
\hline \multirow{2}{*}{ No } & \multirow{2}{*}{ Cities } & \multirow{2}{*}{ Number } & \multicolumn{2}{c}{ Gender } & \multirow{2}{*}{ Note } \\
\cline { 4 - 5 } & & & Male & Female & \\
\hline 1 & Banjar & 28 & 0 & 28 & M=152(33\%) \\
2 & Ciamis & 40 & 10 & 30 & F=309 (67\%); \\
3 & Tasikmalaya & 50 & 8 & 42 & Age $\leq 37=195$ \\
4 & Bandung & 163 & 39 & 124 & $(42 \%)$, \\
5 & Ciranjang & 80 & 35 & 45 & Age $\leq 38=266$ \\
6 & Cianjur & 100 & 60 & 40 & $(58 \%)$ \\
& Total & 461 & 152 & 309 & \\
& & & $(33 \%)$ & $(67 \%)$ & \\
\hline
\end{tabular}

As clearly noted that the respondents come from 6 different cities with the total number is 461 ( 152 of them are male, and 309 female; 195 under or at 37 years of age, and 266 at or over 38 years of age).

\section{RESULT AND DISCUSSION}

Majelis Taklims (hence, MT) are established in almost every locality (kampung), in which participants (jamaah) gather to run learning activities under the guidance and supervision of ustadzs or ustadzah. In terms of the gender, the majelises under study were dominated by women participants $(67 \%)$, i. e. 309 of the 461 total participants, while in terms of the age, the percentage is almost the same, i. e. $42 \%$ from the 37 and below age group, and 58\% from the 38 and above group. To give a clearer idea, see the schematic representation of the data in Figure 1.

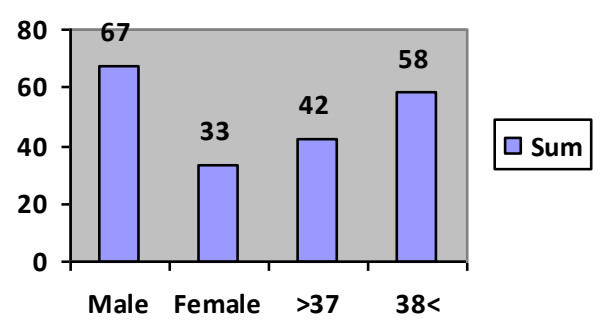

Fig. 1. Data of Repondents' Background

While in terms of gender, the pattern is relatively stable in the last three decades, there is an interesting change in terms of the age group. In the past, MT were dominated by middle-aged to old-aged participants. Today, the percentage of younger participants is also significant.

In the meantime, in terms of the length of time of involvement, frequency and duration of attendance, $71 \%$ have been in the MT for more than 11 years, while the rest below the span; and $72 \%$ attend the sessions twice a week, and $28 \%$ more three times and more. The patterns show that within the last decade, only $29 \%$ of 461 newcomers join MTs, while the rest have already been there before the newcomers' participation. In addition, the majority of the participants spent twice a week, only $28 \%$ spent more. To be clear, the data has been represented in Figure 2.

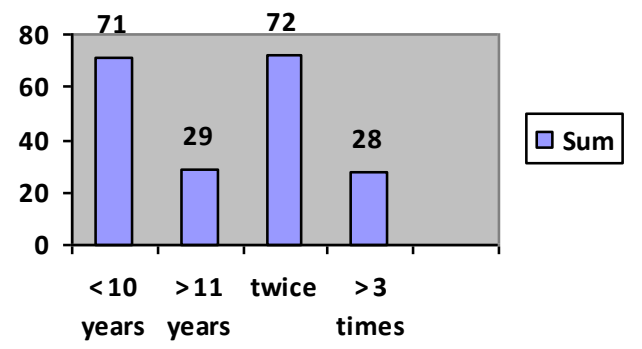

Fig. 2. The Length of Time of Involvement and Frequency of Attendance

In terms of $\mathrm{Al}$ Quran reading Fluency and Arabic literacy, $83 \%$ are fluent, and only $17 \%$ are less fluent; and $84 \%$ are very good and $16 \%$ are fair enough in writing Arabic texts. This indicates that, in terms of Arabic literacy, especially for the purpose of Qur'anic studies, the majority of Indonesian Muslims may have a wide access to Arabic-based literature. However, as suggested by many scholars, there has still to be critical breakthrough to improve Indonesian Muslims' comprehension on Arabic and Qur'anic literature. Many of the methods used are less effective in developing learners' comprehension of the texts. This is evident in the fact that only $24 \%$ of the participants that can achieve the level of the ability of reading Scholar-written Arabic books (kitab kuning), while the rest $(76 \%)$ can only read Al Quran-an textually without attending the meanings. 


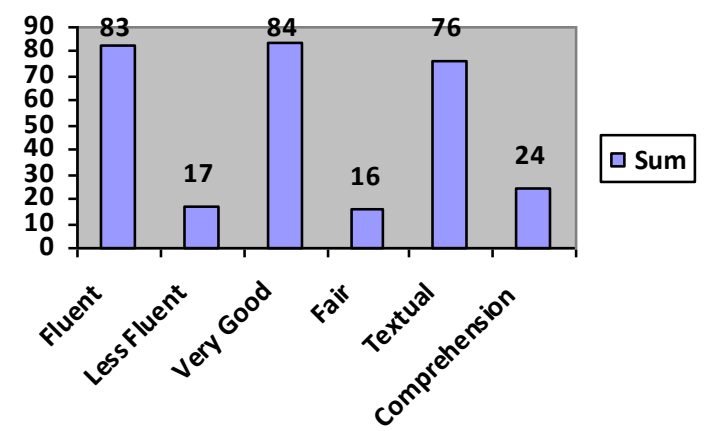

Fig. 3. Al Qur-an Reading Fluency and Arabic Literacy

In terms of the coverage and benefits, $25 \%$ reported that they learn fiqh, $11 \%$ tasawuf, $18 \%$ hadith, and the rest learn to read $\mathrm{Al}$ Quran. In the meantime, $67 \%$ of the participants get stronger religious conviction, and $33 \%$ get more tranquility. In addition, $77 \%$ said that they got more knowledge, and 33\% got more friends. There seem to be a linearity between learning to read Qur'anic texts and the knowledge that they gained; in similar modes, tasawuf and other relevant subjects seem to result in tranquility in the parts of the learners.

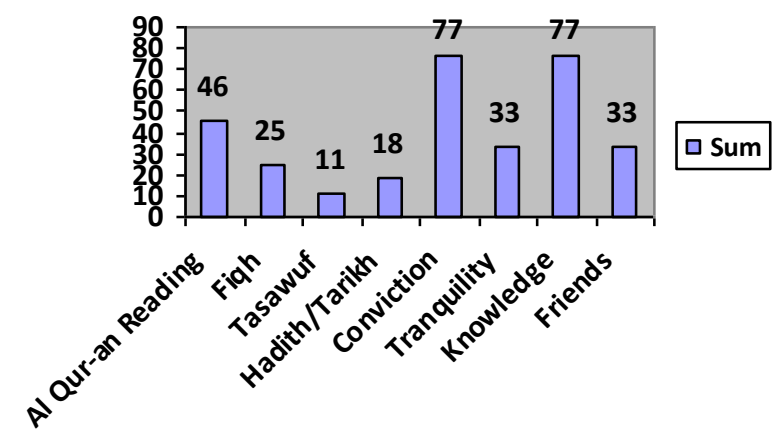

Fig. 4. Benefit and Impact of Learning in MT

To sum up, MT has been reported to have significant contribution to lifelong learning in Indonesia, especially among the Muslims. This study has elaborated the characteristic features of MT, especially in the view of the respondents. It has been shown that the majority of the participants are women, middle-aged, regular, sustained, fluent in textual reading, more convinced, tranquil, and get more knowledge and friends. They are, however, smaller in number in terms of comprehending the Qur'anic and Arabic texts.

In the meantime, in terms of the gender, the patterns are also predictable. Female is dominant in both groups with 10 or less years of involvement (43 to 91) and with 11 or over years of involvement (109 to 218). In terms of competence of reading Arabic texts, the case is a little bit different, the ratio is 120 to 263 of fluent group, meaning that more female participants than male who are fluent; while in the group of less fluent, it is 32 to 46 , which means that the number of less fluent female is bigger than male. In terms of competence of writing Arabic texts, the superiority of female is perfect, bigger number in fluent group, and smaller in less fluent. To get a comprehensive picture, see Table 3.

TABLE III. COMPARATIVE DATA OF MALE AND FEMALE PARTICIPANTS IN TERMS OF TIME OF INVOLVEMENT, READING AND WRITING ARABIC TEXTS COMPETENCE

\begin{tabular}{lllllll}
\hline & Time & & Reading & Writing \\
\hline Gender & $\leq 10$ th & $\geq 11$ th & Fluent & Less & Fluent & Less \\
& & & & Fluent & & Fluen \\
Male & 43 & 109 & 120 & 32 & 110 & 42 \\
& $(28 \%)$ & $(72 \%)$ & $(79 \%)$ & $(21 \%)$ & $(73 \%)$ & $(27 \%)$ \\
Female & 91 & 218 & 263 & 46 & 276 & 33 \\
& $(30 \%)$ & $(70 \%)$ & $(85 \%)$ & $(15 \%)$ & $(89 \%)$ & $(11 \%)$ \\
Total & 134 & 327 & 383 & 78 & 386 & 75 \\
& 461 & & 461 & & 461 & \\
\hline
\end{tabular}

In terms of the use, output and impacts, the data may be found in Table 3.

TABLE IV. COMPARATIVE DATA OF MALE AND FEMALE PARTICIPANTS IN TERMS OF THE USE, OUTPUT, AND IMPACTS OF LIFELONG LEARNING ACTIVITIES IN MAJLIS TAKLIM

\begin{tabular}{|c|c|c|c|c|c|c|}
\hline & Use & & Output & & Impact & \\
\hline Gender & $\begin{array}{l}\text { Readin } \\
\mathrm{g} \\
\text { Quran }\end{array}$ & $\begin{array}{l}\text { Arabic } \\
\text { Literacy }\end{array}$ & $\begin{array}{l}\text { Tranquali } \\
\text { ty }\end{array}$ & Plety & $\begin{array}{l}\text { More } \\
\text { Knowled } \\
\text { ge }\end{array}$ & $\begin{array}{l}\text { More } \\
\text { Friends }\end{array}$ \\
\hline Male & $\begin{array}{l}120 \\
(79 \%)\end{array}$ & $32(21 \%)$ & $58(38 \%)$ & $\begin{array}{l}94 \\
(62 \%)\end{array}$ & $\begin{array}{l}102 \\
(67 \%)\end{array}$ & $\begin{array}{l}50 \\
(33 \%)\end{array}$ \\
\hline Female & $\begin{array}{l}231 \\
(75 \%)\end{array}$ & $78(25 \%)$ & $97(31 \%)$ & $\begin{array}{l}212 \\
(69 \%)\end{array}$ & $\begin{array}{l}254 \\
(82 \%)\end{array}$ & $\begin{array}{l}55 \\
(18 \%)\end{array}$ \\
\hline Total & $\begin{array}{l}351 \\
461\end{array}$ & 110 & $\begin{array}{l}155 \\
461\end{array}$ & 306 & $\begin{array}{l}356 \\
461\end{array}$ & 105 \\
\hline
\end{tabular}

As shown in the table, in all measures, female is more dominant than male. In the meantime, the betterment of reading Quran ability is far more evident than that of Arabic literacy; piety is far more evident than tranquility, and knowledge is far more evident than friends.

\section{CONCLUSIONS}

Based on the findings, some conclusions may draw. First, there have been more women participating in MTs than men; while in terms of the age, younger participants are beginning to increase in number. In the meantime, participation has been regular, and sustained; the majority is fluent in both reading textual Quran and Arabic texts. In addition, they felt more convinced, tranquil, more knowledgeable, and having more friends. Based on their sustainability and contribution, it is reasonable to argue that MT and Arabic literacy has played significant roles in sustaining lifelong learning in Indonesia, especially among the Muslims, the majority of the nation population. However, there is still a homework that this nation should do, i. e. their fluency in textual reading of Al Quran and Arabic texts is not yet accompanied by good text comprehension. For the very reason, it is suggested that MT is improved in terms of the balanced focus, not only on textual features but also meaning aspects so that the participant will get more benefits from their involvement in MTs activities. 


\section{REFERENCES}

[1] Crease, J. "Lifelong learning is the battering ram against inequality", in Adults Learning, 12(4), 7-8, December 2000

[2] Ryan, P. "Lifelong learning: Potential and constraints with special reference to policies in the United Kingdom and Europe". Skills Development Department, ILO, Geneva. Retrieved from www. ilo.org/wcmsp5/groups/public/---ed_emp/---ifp.../wcms_103988.pdf

[3] Smethurst, R. (1995)'Education: a public or private good?' RSA Journal Volume CXLIII No.5465, 33-45, December 1995.

[4] One data indonesia. Jumlah Lembaga Dakwah Menurut KabupatenKota 2011 at http://data.go.id/dataset/jumlah-lembaga-dakwah-menurutkabkota-dki-jakarta/resource/c9686143-2fb3-47ef-930c-b68906c49ce3

[5] Forbes, S. H. Values in Holistic Education, Third Annual Conference on 'Education, Spirituality and the Whole Child' June 28, 1996

[6] Forbes, S. H., and Martin, R. A. What Holistic Education Claims About Itself: An Analysis of Holistic Schools' Literature Presented to the Wholistic Education SIG at the American Education Research Association Annual Conference San Diego, California, April 2004
[7] Forbes, S. H. Holistic Education: An Analysis of its Ideas and Nature. Brandon, VT: Foundation for Educational Renewal. 2003

[8] Bernstein, B. (1996). Pedagogy, Symbolic Control, and Identity: Theory, Research, Critique. London: Taylor \& Francis.

[9] Hill, P. C., \& Pargament, K. I. (2003). Advances in the conceptualization and measurement of religion and spirituality: Implications for physical and mental health research. American Psychologist, 58, 64-74.

[10] Powell, L. H., Shahbi, L., and Thoresen, C. E. Religion and Spirituality: Linkages to Physical Health. American Psyhologist, 58, 36-52, 2003.

[11] MOEC, 2016a, Regulation of the Ministry of Education and Culture of Republic of Indonesia No. 212016 on Standard of Contents (Kemendikbud, 2016a. Permendikbud No. 21 Tentang Standar Isi).

[12] La Belle, T. J. Formal, Nonformal, and Informal Education: a Holistic Perspective on Lifelong Education. International Review of Education, Volume 28, Issue 2, pp 159-175, June 1982.

[13] MOEC, 2016b, Regulation of the Ministry of Education and Culture of Republic of Indonesia No. 222016 on Standard of Process (Kemendikbud, Permendikbud No. 21 Tentang Standar Proses) 